See Article page 1535.

\section{Commentary: The fate of the saphenous vein conduit in coronary bypass}

\author{
Arman Arghami, MD, and Juan A. Crestanello, MD
}

Saphenous veins have been used as coronary bypass conduits for more than 50 years with long-term outcomes inferior to arterial conduits. This has resulted in percutaneous interventions to catch up and sometimes surpass the long-term patency results of saphenous vein grafts. On the other hand, the internal thoracic artery (ITA) remains superior with excellent long-term patency and improved survival in repeated studies. Therefore, many surgeons use bilateral ITAs as in situ or composite grafts and have shown the best long-term patency. ${ }^{1,2}$ But use of bilateral ITAs can be limited by their length, number of distal targets, and slight increase in risk of sternal wound infection. ${ }^{1}$ The present study provides a new horizon as to ways to improve saphenous vein conduit patency. They used the saphenous vein as part of a composite graft based on in situ ITA and showed comparable 10-year patency to other arterial conduits.

Although this is a retrospective study, its long-term imaging follow-up (present for $44 / 103$ patients at 10 years) makes it a valuable study. ${ }^{3}$ It is also important to note the use of no-touch technique and valvulotomy in the study, as well as harvest of the lower leg saphenous vein to avoid size discrepancy. Other studies ${ }^{4}$ have shown near ITA patency rates for veins harvested with the no-touch technique and improved patency with valvulotomy. ${ }^{5}$ Unfortunately, the study does not provide us with saphenous veins anastomosed directly to the aorta as a control group (presumably because of their practice pattern). Despite this limitation, the authors have shown greater than $90 \%$ 10 -year patency rates for a saphenous vein conduit. These are significantly better results than usually published on saphenous vein conduit patency and percutaneous stenting.

\footnotetext{
From Cardiovascular Surgery, Mayo Clinic, Rochester, Minn.

Disclosures: Authors have nothing to disclose with regard to commercial support. Received for publication Feb 20, 2020; accepted for publication Feb 20, 2020; available ahead of print March 12, 2020.

Address for reprints: Juan A. Crestanello, MD, Mayo Clinic, 200 First St SW, JO-

5200, Rochester, MN 55905 (E-mail: Crestanello.Juan@mayo.edu).

J Thorac Cardiovasc Surg 2021;162:1547

$0022-5223 / \$ 36.00$

Copyright (c) 2020 by The American Association for Thoracic Surgery

https://doi.org/10.1016/j.jtcvs.2020.02.100
}

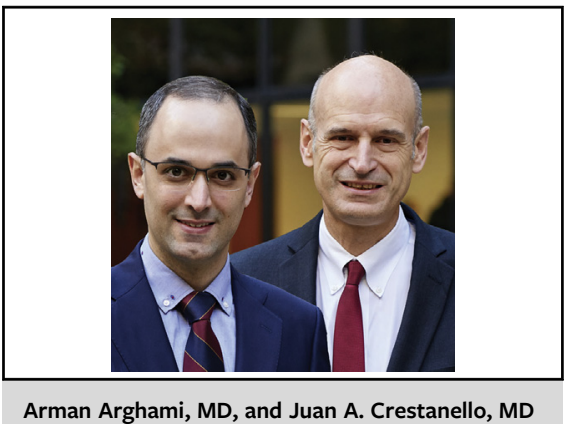

\section{CENTRAL MESSAGE \\ The present study improved saphenous vein conduit 10-year patency by using it in a compos- ite arterial graft configuration.}

In our surgical patients with growing complexity, significant comorbidities, and need for multiple bypasses, to remain relevant we need to provide them with the best shortand long-term results that would surpass those of percutaneous interventions. This study, despite its limitations, has shown superior results with composite saphenous vein grafts allowing surgeons to improve the number of bypassed targets with long-term patency rates perhaps equal to arterial conduits.

\section{References}

1. Locker C, Schaff HV, Daly RC, Dearani JA, Bell MR, Frye RL, et al. Multiple arterial grafts improve survival with coronary artery bypass graft surgery versus conventional coronary artery bypass grafting compared with percutaneous coronary interventions. J Thorac Cardiovasc Surg. 2016;152:369-79.e4.

2. Glineur D, Boodhwani M, Hanet C, de Kerchove L, Navarra E, Astarci P, et al. Bilateral internal thoracic artery configuration for coronary artery bypass surgery: a prospective randomized trial. Circ Cardiovasc Interv. 2016;9(7).

3. Hwang HY, Lee Y, Sohn SH, Choi JW, Kim KB. Equivalent 10-year angiographic and long-term clinical outcomes with saphenous vein composite grafts and arterial composite grafts. J Thorac Cardiovasc Surg. 2021;162:1535-43.e4.

4. Sepehripour AH, Jarral OA, Shipolini AR, McCormack DJ. Does a 'no-touch' technique result in better vein patency? Interact Cardiovasc Thorac Surg. 2011; 13:626-30

5. Chaux A, Ruan XM, Fishbein MC, Sandhu M, Matloff JM. Influence of vein valves in the development of arteriosclerosis in venoarterial grafts in the rabbit. J Thorac Cardiovasc Surg. 1995;110:1381-90. 